\title{
STUDI SOSIOLOGI PERNIKAHAN MUBARAK DI PONDOK PESANTREN HIDAYATULLAH MAKASSAR
}

\author{
Nurul Fathiyyatul Mufidah ${ }^{1}$, Andi Agustang ${ }^{2}$ \\ 1,2Program Studi Sosiologi, Fakultas Ilmu Sosial, Universitas Negeri Makassar \\ nrlffida@gmail.com ${ }^{1}$, andiagust63@gmail.com ${ }^{2}$
}

\begin{abstract}
ABSTRAK
Penelitian ini dilakukan untuk mengetahui: 1) bagaimana sistem Pernikahan Mubarak; dan 2) apa latar tindakan sosial peserta Pernikahan Mubarak di Pondok Pesantren Hidayatullah Makassar. Jenis penelitian ini adalah kualitatif deskriptif. Informan sebanyak 6 orang ditentukan dengan metode snowball sampling dengan pihak pertama yaitu ketua pelaksana Pernikahan Mubarak, ustadz-ustadz yang terlibat dalam proses perjodohan, peserta dan lembaga yang ikut serta dalam melaksanakan Pernikahan Mubarak. Data dikumpulkan dengan cara observasi, wawancara serta dokumentasi. Data yang ditemukan dianalisis menggunakan teoti tindakan sosial Max Weber. Hasil penelitian ini ditemukan bahwa, 1) Pernikahan Mubarak menggunakan sistem pernikahan yang syar'i atau sesuai dengan aturan dan anjuran dalam agama Islam. Pernikahan ini awalnya diperuntukkan untuk kader Hidayatullah untuk menghindari hubungan antara pria dan wanita di luar pernikahan seperti berpacaran dan untuk meringankan beban seseorang yang akan menikah salah satunya dari segi biaya. 2) Secara umum, latar tindakan peserta Pernikahan Mubarak, yaitu tindakan rasional nilai yang berorintasi pada nilai agama islam karena pernikahan ini dilaksanakan berdasar pada anjuran dan ketentuan agama islam. .
\end{abstract}

Kata kunci: perjodohan, pernikahan mubarak, pesantren, tindakan sosial

\section{ABSTRACT}

This research was conducted to find out: 1) how the Mubarak Marriage system; and 2) what is the background of the social actions of Mubarak Marriage participants at Hidayatullah Islamic Boarding School in Makassar. This type of research is descriptive qualitative. 6 informants were determined by the snowball sampling method with the first party, namely the chief executive of Mubarak Marriage, religious teachers who were involved in the matchmaking process, participants and institutions that participated in carrying out Mubarak Marriage. Data collected by observation, interview and documentation. The data found was analyzed using Max Weber's social action theory. The results of this study found that, 1) Mubarak Marriage uses a shar'i marriage system or in accordance with the rules and recommendations in the Islamic religion. This marriage was originally intended for cadre Hidayatullah to avoid relationships between men and women outside of marriage such as dating and to ease the burden of someone who is getting married one of them in terms of cost. 2) In general, the setting of the actions of Mubarak Marriage participants, namely the rational actions of values which are oriented to the value of Islamic religion because this marriage is carried out based on the recommendations and provisions of the Islamic religion.

Keywords: arranged marriages, marriage mubarak, boarding schools, social action

\section{PENDAHULUAN}

Pernikahan merupakan cara resmi yang disetujui dalam masyarakat ketika dua individu bersedia hidup bersama dan menjadi keluarga. Pernikahan atau perkawinan dilaksanakan dengan tujuan untuk melanjutkan keturunan, mencegah terjadinya pergaulan bebas tanpa ikatan yang resmi, serta sebagai pelengkap ibadah. Pernikahan yang baik akan membentuk masyarakat yang baik pula, karena awal dari masyarakat adalah keluarga yang merupakan unit terkecil dalam masyarakat yang terbentuk dari sebuah pernikahan.

Proses yang dilalui orang-orang untuk mencapai tahap perkawinan memiliki latar belakang yang berbeda-beda. Proses memulai hubungan yang paling umum dan banyak dilakukan oleh remaja di Indonesia adalah dengan berpacaran. Menurut Santrock dalam (Hidayat \& Wardana, 2018) pacaran dapat menjadi bagian dari hiburan, mencari status, 
atau suatu keadaan yang digunakan untuk mempelajari suatu hubungan yang terjalin antara laki-laki maupun perempuan. Namun, berpacaran dilarang dalam Islam karena dapat mendekatkan pelakunya ke arah zina, seperti yang tercantum dalam QS Al-Isro' ayat 32 yang berarti:

"Dan janganlah kamu mendekati zina. Sesungguhnya zina itu suatu perbuatan yang keji dan suatu jalan yang buruk” (QS Al-Isro':32).

Pacaran di lingkungan pesantren merupakan pelanggaran yang besar karena telah melampaui aturan agama, karenanya dilakukanlah konsep hijab yang dalam bahasa arab berarti penghalang atau pembatas yang menjadi aturan yang dijunjung tinggi dilingkungan pesantren. Salah satu contohnya dapat dilihat dari konsep batasan yang dibentuk antara santri putra dan santri putri dimana asramanya yang diletakkan berjauhan dan lokasi belajar yang berbeda. Adanya batasan-batasan tersebut tidak memungkinkan terjadinya suatu hubungan seperti berpacaran dalam lingkungan pesantren, jikalau pun ada dan kemudian ketahuan maka akan diberi hukuman oleh pihak pesantren.

Untuk menghindari terjadinya hubungan-hubungan yang dilarang oleh agama kemudian beberapa pesantren di Indonesia berinisiatif mengadakan perjodohan antar santrinya. Perjodohan merupakan salah satu konsep membentuk hubungan untuk menuju tahap perkawinan. Perjodohan adalah perkawinan dua individu dimana calon pengantin dipilih oleh individu diluar dari pasangan itu sendiri. Orang yang dipercayakan untuk memasangkan pengantin umumnya adalah orang yang telah dipercaya, berilmu dan berpengalaman.

Salah satu contoh pesantren yang melakukan prjodohan antar santrinya, yaitu Pondok Pesantren Hidayatullah. Perjodohan yang terjadi di Pondok Pesantren Hidayatullah ini masuk ke dalam tradisi pernikahan massal yang telah menjadi program lembaga ini. Pernikahan massal merupakan proses sakral dengan menikahkan beberapa pasangan yang telah melalui proses perjodohan yang ketat dan tidak mengenal antara yang satu dan yang lain sebelumnya.

Pernikahan massal di Hidayatullah pertama kali dilaksanakan pada 6 Maret 1977 yang hanya diikuti oleh 2 pasang santri, yaitu Abdul Qadir Jailani dengan Nurhayati dan Sabrini Nasir dengan Salmiyah. Setelah pernikahan massal pertama itu, kegiatan ini konsisten dilakukan mulai dari 4 pasangan hingga puluhan pasang yang kemudian menjadikan kegiatan ini sebagai tradisi.

Tradisi pernikahan massal di Hidayatullah masih rutin dilaksanakan di berbagai kampus-kampus Pondok Pesantren Hidayatullah di Indonesia. Salah satu cabang Pondok Pesantren Hidayatullah Sulawesi berada di Makassar, tepatnya di kompleks Bumi Tamalanrea Permai (BTP) juga rutin mengadakan pernikahan massal. Pada 11 November 2017, pernikahan massal Hidayatullah Makassar yang diikuti oleh 9 pasang santri dan saksi nikah oleh Wali Kota Makassar saat itu, yaitu Moh Ramadhan Pomanto dan wakilnya Syamsu Rizal, serta beberapa ulama Kota Makassar (Hidorid, 2017).

Kemudian yang terbaru pada bulan Agustus tahun 2019 Pernikahan Massal Mubarak kembali dilaksanakan di Pesantren Hidayatullah Sulawesi Selatan yang berlokasi di Pare-Pare dengan diikuti oleh 24 santri dan santriwati yang dipasangkan. Pernikahan Massal Mubarak ini dilaksanakan di daerah yang memiliki peserta terbanyak, jadi seperti pada pernikahan massal 2019 kemarin peserta dari Makassar tidak lebih banyak dari peserta yang ada di Pare-Pare, maka kemudian kegiatan Pernikahan Massal Mubarak dilaksanakan di Pesantren Hidayatullah Sulawesi Selatan cabang Pare-Pare.

Dalam memulai suatu tindakan individu tentunya memiliki motif dan tujuan yang melatar belakangi mereka dalam memutuskan tindakannya, begitu pula dengan peserta 


\section{Jurnal Sosialisasi \\ Jurnal Hasil Pemikiran, Penelitian, dan Pengembangan \\ Keilmuan Sosiologi Pendidikan \\ Vol 7, Nomor 2, Juli 2020}

yang ikut dalam Pernikahan Mubarak ini tentunya memiliki tujuan dan alasan mereka sendiri sehingga memutuskan untuk menjadi peserta. Teori dapat memberi petunjuk tentang kejelasan hubungan diantara konsep-konsep fenomena pada klasifikasi tertentu (Agustang, 2011a), teori yang digunakan dalam penelitian ini, yaitu teori Tindakan Sosial oleh Max Weber. Berdasarkan penjelasan di atas kemudian penulis tertarik untuk mengetahui lebih dalam mengenai sistem Pernikahan Mubarak di Pondok Pesantren Hidayatullah Makassar dan latar belakang tindakan sosial para peserta untuk menikah pada Pernikahan Mubarak

\section{METODE PENELITIAN}

Pengetahuan dapat diperoleh dari pengalaman tanpa memahami secara ilmiah, sedangkan ilmu dapat dipahami sebagai kumpulan pengetahuan yang menjelaskan suatu objek secara sistematis dengan metode tertentu (Agustang, 2015). Penelitian ini merupakan penelitian deskriptif kualitatif yang mengungkapkan suatu masalah dengan menggambarkannya sesuai dengan keadaan atau berdasarkan fakta yang ada di lapangan. Kualitatif merujuk pada kehidupan nyata manusia yang terkait dengan gejala dibalik segala tindakannya sebagai makhluk sosial (Agustang, 2011b). Lokasi penelitian ini dilaksanakan di Makassar, Sulawesi Selatan, tepatnya di Pondok Pesantren Hidayatullah cabang Makassar yang berdiri di Kompleks Bumi Tamalanrea Permai.

Dalam menentukan informan pada penelitian ini, penulis menggunakan teknik snowball sampling, dengan pihak pertama yaitu ketua pelaksana Pernikahan Massal Pondok Pesantren Hidayatullah Makassar, Ustadz-ustadz yang terlibat dalam proses perjodohan, peserta dan lembaga yang ikut serta dalam melaksanakan program pernikahan massal. Pengumpulan data menggunakan cara observasi, wawancara dan dokumentasi. Teknik analisis data penelitian ini terdiri dari tiga tahapan kerja, yakni: reduksi data, display data, serta kesimpulan. Adapun teknik pengabsahan data dengan member check.

\section{HASIL PENELITIAN DAN PEMBAHASAN}

\section{Sistem Pernikahan Mubarak di Pondok Pesantren Hidayatullah Makassar}

Pada bagian ini dijelaskan bagimana sistem, proses dan cara yang dilaksanakan oleh panitia dan ustadz-ustadz dalam rangkaian pelaksanaan progran Pernikahan Mubarak.

Pernikahan Mubarak yang dilakukan oleh Yayasan Pondok Pesantren Hidayatullah Makassar pada awalnya untuk memberikan kesempatan bagi para kadernya yang aktif berdakwah dan mengabdi pada yayasan dan belum memiliki pasangan sementara ia sudah siap menikah untuk kemudian dinikahkan. Selain itu, program ini dihadirkan untuk membantu dan meringankan beban seseorang yang akan menikah, salah satunya dari segi biaya khususnya bagi pihak laki-laki yang biasanya perlu mengeluarkan biaya besar jika akan melaksanakan pernikahan. Untuk mengikuti Pernikahan Mubarak yang dilaksanakan oleh Hidayatullah ini tidak memerlukan biaya yang besar bahkan pihak pesantren juga menyesuaikan biaya dari kemampuan para pesertanya.

Dinamakan Pernikahan Mubarak karena diharapkan pernikahan yang terjadi dalam program ini berbuah keberkahan karena dilaksanakan sesuai dengan syari'at Islam. Selain persoalan biaya yang kerap menjadi masalah untuk memulai pernikahan yang biasa terjadi di masyarakat, pelanggaran syari'at Islam seperti berpacaran sebelum menikah dan prosesi pernikahan yang tidak sesuai dengan syari'at Islam juga menjadi penyebab yayasan Hidayatullah melaksanakan Pernikahan Mubarak ini. 


\section{Jurnal Sosialisasi \\ Jurnal Hasil Pemikiran, Penelitian, dan Pengembangan \\ Keilmuan Sosiologi Pendidikan \\ Vol 7, Nomor 2, Juli 2020}

Sebuah sistem perlu mendefinisikan dan mencapai tujuan utamanya. Pernikahan Mubarak ini dilakukan sekaligus untuk menjadi sarana dakwah untuk menjalankan pernikahan secara syar'i sesuai dengan anjuran dan ketentuan dalam agama Islam. Pernikahan yang dilakukan secara syar'i ini pun diharapkan dapat menciptakan keluarga yang sakinah, mawaddah dan rahmah bagi para pesertanya, karena itulah tujuan utama yang ingin dicapai para panitia dan juga peserta karena peserta-peserta yang terpilih dan dipasangkan kepada mereka merupakan hasil istikharah dan proses musyawarah yang panjang oleh ustadz-ustadz yang telah dipercayakan oleh panitia Pernikahan Mubarak.

Peserta yang diikutkan dalam program ini merupakan hasil observasi dan telah dipilih serta diseleksi langsung oleh pihak pesantren dan panitia, jadi selama mereka mondok ataupun mengabdi di Yayasan Hidayatullah, mereka diperhatikan individunya. Adapun kriteria yang dilihat pertama dari usia tiap individu apakah sudah mencapai usia yang sudah dianggap matang atau belum. Yang kedua, dilihat dalam kesehariannya apakah sudah mandiri dan telah dewasa untuk mulai berkeluarga dan juga memiliki akhlak yang baik. Jika sudah memenuhi kriteria usia matang, berperilaku dewasa dan memiliki akhlak yang baik, maka pihak pesantren kemudian menawarkan dan menanyakan apakah individu tersebut siap untuk mengikuti Pernikahan Mubarak.

Adapun jika ada orang luar yang berkeinginan untuk ikut menjadi peserta dalam Pernikahan Mubarak, maka terlebih dahulu harus memenuhi kriteria yang diatas dan mendapatkan rekomendasi dari orang dalam pesantren karena pihak yayasan hanya menerima peserta dari luar yang merupakan rekomendasi dari orang Hidayatullah itu sendiri.

Selain beberapa kriteria yang telah dijelaskan sebelumnya, para peserta baik itu dari dalam maupun luar pesantren perlu untuk berkomitmen untuk mengabdi di lembaga Hidayatullah dan menjadi kader serta aktif dalam setiap kegiatan lembaga. Mengabdi yang dimaksudkan disini berarti dia siap untuk mengabdikan dirinya dengan mengajar, berdakwah, atau dengan hal yang lain sesuai dengan keahliannya dan bersedia ditempatkan di Hidayatullah cabang manapun sesuai dengan ketetapan dari pihak pesantren.

Setelah peserta menyatakan bersedia untuk ikut dalam Pernikahan Mubarak dan menandatangani surat pernyataan bersedia, kemudian peserta terlebih dahulu harus mengikuti beberapa tahapan untuk mempersiapkan mentalnya, karena menikah pada pernikahan mubarak ini memerlukan mental yang kuat karena para peserta sebelumnya tidak tahu dan belum pernah bertemu dengan peserta lain yang akan dipasangkan dengan dirinya.

Tahap pertama yaitu, peserta menerima pasangan yang akan dipasangkan dengan dirinya, penerimaan ini tidak dengan paksaan sama sekali dari pihak panitia, jika pada awalnya peserta menolak kemudian panitia akan memberikan pengertian, jika kemudian dianggap sudah siap selanjutnya peserta melanjutkan ke tahap administrasi dimana peserta perlu mempersiapkan berkas-berkas yang termasuk dalam syarat untuk melaksanakan pernikahan. Setelah itu peserta dapat meneruskan ke tahap kedua, yaitu pembekalan.

Tahap pembekalan ini biasanya berlangsung selama satu minggu. Peserta laki-laki dan perempuan menerima materi pembekalan pada lokasi yang berbeda. Adapun materimateri yang diberikan pada peserta berupa materi yang terkait dengan pernikahan, bagi peserta laki-laki akan diberi materi mengenai bekal untuk menjadi seorang kepala keluarga, sedangkan bagi peserta perempuan akan diberikan materi mengenai bekal untuk menjadi ibu rumah tangga. Selain kedua tema tersebut peserta juga diberikan materi-materi mengenai bekal untuk menjadi da'i, guru, dan lain sebagainya, sebagai bekal para peserta untuk mengabdi nantinya. 


\section{Jurnal Sosialisasi \\ Jurnal Hasil Pemikiran, Penelitian, dan Pengembangan \\ Keilmuan Sosiologi Pendidikan \\ Vol 7, Nomor 2, Juli 2020}

Panitia sendiri juga melalui beberapa tahapan dalam memasangkan para pesertanya. Pada tahap memasangkan para peserta dipegang oleh panitia perjodohan atau juga biasa disebut steering perjodohan yang terdiri ustadz-ustadz senior di yayasan Hidayatullah Makassar. Dalam proses perjodohan ini ustadz-ustadz berkumpul, bermusyawarah memasangkan para peserta dengan melihat beberapa aspek dari latar belakangnya mulai dari yang paling penting yaitu, agama dan akhlaknya, kemudian pendidikan, tempat tinggal asal, karakter kultur asalnya dan lain-lainnya.

Pada tahap ini juga dilibatkan pembina santri putra maupun putri karena mereka dinilai dekat dan paham dengan peserta yang telah lama mondok ataupun mengabdi di pesantren. Jadi, panitia dan pembina saling bertukar informasi terkait para peserta dan menggambarkan bagaimana si peserta tersebut untuk disesuaikan kepribadiannya dengan peserta lain yang akan menjadi pasangannya.

Setelah dimusyawarahkan, para pasangan ini tidak serta merta kemudian langsung dijodohkan, namun terlebih dahulu didoakan kepada Allah SWT untuk mengharapkan keridaan serta bantuan-Nya, lalu kemudian dishlalat istikharahkan. Istikharah disini ialah shalat untuk meminta petunjuk kepada Allah SWT dalam memasangkan para peserta Pernikahan Mubarak ini. Jika setelah hal-hal tersebut dilakukan namun panitia merasa masih ada yang belum cocok, maka akan disholat istikharahkan lagi. Proses tersebut dapat terjadi sampai beberapa kali dan memakan waktu bisa berbulan-bulan sampai benar-benar diyakini bahwa tidak ada lagi yang menghalangi dan dirasa pasangan ini betul sudah sesuai.

Pada Pernikahan Mubarak ini, Yayasan Hidayatullah tidak serta merta langsung menjodohkan para pesertanya karena yayasan hanya memegang peran sebagai penyedia sarana untuk menikah, jadi tetap memerlukan perizinan dari tiap orangtua ataupun wali dari tiap peserta Pernikahan Mubarak. Saat akan melamar, pihak pesantren atau panitia mewakili peserta pria untuk datang melamar. Jadi, pihak pesantren datang ke setiap daerah asal peserta perempuan untuk menemui orang tua atau walinya tanpa mengikutkan peserta pria. Saat itu, panitia menjelaskan ke tiap orang tua atau wali peserta siapa yang akan menjadi calon anaknya dan bagaimana latar belakangnya dan juga diperlihatkan fotonya, jadi yang diperlihatkan foto itu hanya wali tiap peserta dan peserta tidak akan diperlihatkan sampai pada hari penerimaan mahar.

Pada proses pelamaran ini tidak selamanya berjalan sesuai dengan rencana panitia, kadang ada orang tua yang ragu-ragu bahkan menolak anaknya dipasangkan dengan calon yang dilamarkan pada anaknya. Disini kemudian panitia menjelaskan maksud dan tujuan pesantren dalam mengadakan program ini, bahwa pernikahan ini bukan semata-mata untuk kepentingan panitia, namun untuk memberikan kemudahan dalam menikah dan mendakwahkan pada masyarakat unuk melaksanakan pernikahan secara syar'i serta sesuai dengan anjuran dan ketentuan dalam agama Islam. Seperti pada wawancara sebelumnya dijelaskan dengan diberi pemahaman seperti ini biasanya para orang tua pun perlahanlahan mulai mengerti dan merestui anaknya.

Malam hari sebelum hari dilangsungkannya pernikahan kemudian diberitahukan kepada para peserta siapa saja yang akan menjadi pasangannya dan dinikahkan dengannya di esok hari. Bahkan sampai malam ini juga biasa terjadi perubahan pasangan karena berbagai macam masalah, ada yang kabur karena mentalnya belum siap, ada juga yang setelah tahu siapa pasangannya kemudian menolak karena kebetulan dia tahu bagaimana orangnya. Jika hal-hal seperti ini kemudian terjadi maka panitia biasanya bertanya langsung kepada santri yang lain mengenai siapa yang siap untuk menjadi pasangan peserta tersebut. Tapi, hal-hal seperti itu jarang terjadi dan kebanyakan menerima pasangannya karena memiliki mental yang kuat dan pegangan agama yang baik.

Pada hari berlangsungnya acara Pernikahan Mubarak mereka dinikahkan secara satu-persatu oleh ustadz yang telah ditunjuk, setelah dinikahkan di ruangan yang terpisah 


\section{Jurnal Sosialisasi \\ Jurnal Hasil Pemikiran, Penelitian, dan Pengembangan Keilmuan Sosiologi Pendidikan \\ Vo[ 7, Nomor 2, Jufi 2020}

antara peserta laki-laki dan perempuan mereka diberikan nasihat tentang pernikahan yang dibawakan oleh ketua yayasan atau pembina yayasan, kemudian setelah itu keluarga pihak laki-laki menuju ke pihak perempuan untuk melakukan penyerahan mahar, kedua keluarga berkumpul di tempat yang telah disepakati dan disediakan oleh panitia. Setelah penyerahan mahar selesai kemudian dilakukanlah silaturahmi antar kedua keluarga besar.

Setelah acara selesai biasanya dibuat kesepakatan antar orang tua pasangan untuk melaksanakan syukuran pernikahan di kampung asal pihak perempuan sebagai upaya untuk mengumumkan bahwa anak perempuan keluarga tersebut telah melangsungkan pernikahan.

\section{Latar Tindakan Sosial Peserta Pernikahan Mubarak di Pondok Pesantren Hidayatullah Makassar}

Berdasarkan hasil penelitian yang dilakukan oleh penulis, setiap peserta memiliki motivasi yang berbeda-beda yang menjadi latar belakang mereka untuk ikut menjadi peserta pada Pernikahan Mubarak. Dalam melihat latar tindakan informan peserta penulis menggunakan teori tindakan sosial Weber. Menurut Weber, tindakan sosial adalah suatu tindakan individu yang dalam tindakan tersebut memiliki makna atau arti subjektif bagi dirinya dan diarahkan kepada tindakan orang lain. Weber membedakan tindakan sosial ke dalam empat tipe, yang pertama tindakan rasionalitas instrumental (berorientasi tujuan), tindakan rasional nilai (berorintasi pada nilai), tindakan afektif, dan tindakan tradisional (Supraja, 2012)

Tindakan yang pertama yaitu, tindakan rasionalitas instrumental (berorientasi tujuan), tindakan ini merupakan suatu tindakan sosial yang dilakukan seseorang didasarkan atas pertimbangan dan pilihan sadar yang berhubungan dengan tujuan tindakan itu dan ketersediaan alat yang dipergunakan untuk mencapainya. Tindakan ini dilakukan untuk mencapai tujuan dengan pertimbangan rasional.(Muhlis \& Norkholis, 2016)

Dari beberapa wawancara yang dilakukan dapat dilihat bahwa para peserta memiliki latar yang berebeda-beda sehingga mereka memutuskan untuk menjadi peserta pada Pernikahan Mubarak. Sebelum mereka memutuskan untuk menjadi peserta, mereka telah memikirkannya secara rasional dan matang karena seperti yang diketahui bahwa melaksanakan pernikahan bukanlah hal yang dilakukan hanya sehari melainkan akan dijalani oleh tiap peserta seumur hidup mereka dengan penuh tanggung jawab, oleh karena itu mereka perlu memikirkan apa yang akan mereka lakukan secara matang.

Adapun tujuan utama mereka untuk ikut dalam Pernikahan Mubarak ini tentunya untuk mendapatkan pasangan hidup. Mayoritas dari para peserta yang memilih dan bersedia untuk ikut dalam Pernikahan Mubarak karena mereka ingin mendapatkan pasangan yang memiliki agama yang baik dan mereka yakin bahwa pasangan yang telah dipilihkan dan diistikharahkan oleh para ustadz merupakan jodoh mereka yang terbaik karena telah dipilih dan dido'akan langsung oleh ustadz-ustadz yang baik agamanya dan dianggap telah tinggi ilmunya dan juga mereka yang dipasangkan kepada mereka bukanlah orang sembarang, melainkan kader Hidayatullah.

Dari keempat informan peserta Pernikahan Mubarak yang penulis wawancara, mereka semua memiliki memiliki pegangan yang juga memotivasi mereka sehingga yakin untuk ikut dalam Pernikahan Mubarak ini, yaitu seberapa besar usaha panitia untuk menjodohkan mereka dengan seseorang, tidak akan berhasil jika itu bukan jodohnya. Menurut mereka, jika diri ini baik maka mereka akan mendapatkan yang sepadan, oleh karena itu selama mengikuti rangkaian proses Pernikahan Mubarak ini mereka berusaha memperbaiki diri hingga dipertemukan dengan pasangannya pertama kali setelah penyerahan mahar.

Selanjutnya, dalam penelitian ini juga ditemukan adanya tindakan rasional nilai (berorientasi nilai/berdasarkan nilai), tindakan rasional nilai memiliki sifat bahwa alat-alat 
yang ada hanya merupakan pertimbangan dan perhitungan yang sadar, sementara tujuantujuannya sudah ada di dalam hubungannya dengan nilai-nilai individu yang bersifat absolut. Tindakan yang dilakukan berdasarkan pertimbangan nilai etika, adat maupun nilai lainnya.

Nilai agama merupakan nilai yang menjadi motif peserta dalam mengikuti Pernikahan Mubarak ini. Nilai agama adalah salah satu nilai yang menjadi dasar seseorang dalam melakukan suatu tindakan berdasarkan pertimbangan bahwa hal tersebut benar menurut pandangan ajaran agama (Awaru, 2017).

Peserta yang ikut dalam Pernikahan Mubarak ini sebelumnya tidak melalui proses pacaran dan mereka antar peserta laki-laki dan perempuan sebelumnya tidak mengenal satu dengan yang lain. Mereka ikut dalam Pernikahan Mubarak ini karena mereka ingin melakukan pernikahan yang sesuai dengan anjuran dan ketentuan dalam agama Islam. Memang di dalam Islam tidak terdapat syariat yang mengharuskan ataupun melarang perjodohan. Islam hanya memerintahkan untuk seorang Muslim memilih pasangan yang baik agamanya (Dan, n.d.). Seperti yang sudah dijelaskan sebelumnya pada sistem Pernikahan Mubarak bahwa salah satu tujuan dari dilaksanakannya pernikahan ini untuk mewujudkan pernikahan yang berkah dengan memilih peserta yang baik agamanya. Selain itu, pernikahan ini juga dilakukan untuk menghindari terjadinya pelanggaran-pelanggaran agama dalam proses pernikahannya, salah satunya, yaitu berpacaran. Oleh karena itu Pernikahan Mubarak ini dilakukan sekaligus untuk menjadi sarana dakwah untuk menjalankan pernikahan secara syar'i sesuai dengan anjuran dan ketentuan dalam agama Islam(uf bin Dahlan, 2011).

Tindakan yang ketiga, yaitu tindakan tradisional atau tindakan yang disebabkan oleh kebiasaan. Dalam tindakan ini, seseorang memperlihatkan perilaku tertentu karena kebiasaan yang diperoleh dari diri sendiri maupun orang lain, tanpa refleksi yang sadar atau perencanaan.

Pernikahan Mubarak di Pondok Pesantren Hidayatullah cabang Makassar ini telah berlangsung sejak tahun 1996 dan masih terus dilaksanakan hingga saat ini sehingga telah menjadi tradisi tersendiri di Pesantren Hidayatullah. Beberapa peserta Pernikahan Mubarak telah lama tinggal dan mengabdi di pesantren sehingga mereka sering melihat pengalaman senior-senior yang ikut pada Pernikahan Mubarak. Sebab sering melihat pengalaman senior tersebut mereka kemudian muncul keinginan juga untuk mengikuti Pernikahan Mubarak karena tanpa sadar hal tersebut sudah mempengaruhi persepsi mereka terkait pernikahan yang syar'i.

Selain itu, karena sudah terbiasa melihat seniornya dan terbentuk pola pikirnya terkait pernikahan, saat ditawarkan untuk ikut pada Pernikahan Mubarak beberapa kader Hidayatullah menurut saja untuk ikut dengan dalih sami'na wa'athona yang berarti, kami dengar, maka kami taat.

Begitupun juga dengan orangtua peserta yang melihat anaknya sudah lama tinggal di pesantren. Orangtua para peserta mempercayakan semua keputusan terkait pernikahan pada peserta karena melihat anaknya sudah lama menuntut ilmu di pesantren sehingga juga mempengaruhi pemikiran orang tua peserta terkait agama.

Berdasarkan hasil wawancara pada beberapa informan peserta Pernikahan Mubarak yang terlibat dalam penelitian ini, secara umum memutuskan untuk ikut serta pada pernikahan ini karena berdasar pada tindakan rasional nilai / tindakan yang berdasarakan pada beberapa nilai yang dimana pada penelitian ini, yaitu berdasar pada nilai agama islam yang ada pada program Pernikahan Mubarak ini.

Pihak Pesantren Hidayatullah melaksanakan Pernikahan Mubarak ini dengan sangat memperhatikan tiap prosesnya agar sesuai dengan anjuran dan ketentuan dalam agama islam agar terwujudnya pernikahan yang berkah serta agar menghasilkan keluarga yang sakinah,mawaddah dan rahmah. Hal inilah yang kemudian menjadi salah satu sebab 
para peserta sehingga yakin dan memutuskan untuk ikut pada Pernikahan Mubarak yang dilaksanakan oleh pihak pesantren.

\section{PENUTUP}

Sistem Pernikahan Mubarak yang dilaksanakan oleh Pondok Pesantren Hidayatullah Makassar menerapkan sistem pernikahan yang syar'i atau sesuai dengan aturan dan anjuran dalam agama Islam. Pernikahan ini awalnya diperuntukkan untuk kader Hidayatullah dengan latar: 1) untuk menghindari hubungan antara pria dan wanita di luar pernikahan seperti berpacaran dan, 2) untuk meringankan beban seseorang yang akan menikah salah satunya dari segi biaya. Proses pada program Pernikahan Mubarak ini terdiri dari beberapa tahap, mulai dari pendataan santri, wawancara, menandatangani surat pernyataan bersedia, peserta mempersiapkan berkas yang diperlukan, pembekalan pra nikah. Selama proses ini berlangsung di tempat lain, ustadz-ustadz bermusyawarah dan beristikharah dalam proses menjodohkan para peserta. Peserta akan diberitahu nama calon pasangannya pada malam hari sebelum acara dan baru dipertemukan pertama kali setelah akad saat penerimaan mahar.

Latar tindakan perserta Pernikahan Mubarak di Pondok Pesantren Hidayatullah Makassar dapat dilihat dari beberapa tindakan sosial, yaitu tindakan rasionalitas instrumental, tindakan rasional nilai, tindakan tradisional. Secara umum, latar tindakan peserta Pernikahan Mubarak, yaitu tindakan rasional nilai yang berorintasi pada nilai agama karena pernikahan ini dilaksanakan berdasar pada anjuran dan ketentuan agama islam.

\section{DAFTAR PUSTAKA}

Agustang, A. (2011a). Filosofi Research (Dalam Upaya Pengembangan Ilmu). Makassar. Agustang, A. (2011b). Pendekatan Penelitian Kualitatif dan Kuantitatif Suatu Tinjauan Kritis. Makassar: Andira Publisher.

Agustang, A. (2015). Dasar-Dasar Filsafat Penelitian Untuk Pengembangan Ilmu. CV Multi Global, Jalan Maccini Sawah.

Awaru, A. O. T. (2017). Membangun Karakter Bangsa Melalui Pendidikan Berbasis Multikultural Di Sekolah. Prosiding Seminar Nasional Himpunan Sarjana Ilmu-Ilmu Sosial, 2, 221-230.

Dan, J. (n.d.). Etika Perjodohan.

Hidayat, T. T., \& Wardana, A. (2018). Ta'aruf dan Upaya Membangun Perjodohan Islami pada Kalangan Pasangan Muda Muslim di Yogyakarta. E-Societas, 7(7).

Hidorid, R. (2017, November 6). Walikota dan Wakil, Saksi Nikah Pernikahan MUbarak Hidayah Tullah Makassar. Https://Hidayatullah.or.Id/. Retrieved from https://hidayatullah.or.id/read/berita-utama/2017/11/06/walikota-dan-wakil-saksinikah-mubarak-hidayatullah-makassar/

Muhlis, A., \& Norkholis, N. (2016). Analisis Tindakan Sosial Max Weber dalam Tradisi Pembacaan Kitab Mukhtashar Al-bukhari (Studi Living Hadis). Jurnal Living Hadis, $1(2), 242-258$.

Supraja, M. (2012). Alfred Schutz: Rekonstruksi Teori Tindakan Max Weber. Jurnal Pemikiran Sosiologi, 1(2), 81-90.

uf bin Dahlan, D. A. (2011). Aturan Pernikahan Dalam Islam. Lembar Langit Indonesia. 